УДК 657

Камінська I.М., к.е.н., доцент

Дорош В.Ю., к.е.н., доцент

Ковальчук А.Ю., бакалавр

Луцький національний технічний університет

\title{
МЕТОДИЧНІ ПІДХОДИ ДО ОЦІНКИ ЕФЕКТИВНОСТІ ФОРМУВАННЯ ТА ВИКОРИСТАННЯ АКТИВІВ ПІДПРИЕМСТВА
}

\begin{abstract}
У статті досліджено та вдосконалено сучасні методичні підходи до комплексної та системної оцінки ефективності формування та використання активів підприємства. Проаналізовано й здійснено оцінку ефективності формування та використання активів на прикладі ПАТ «Теремно Хліб».

Ключові слова: активи підприємства, оборотні активи, необоротні активи, основні засоби, ефективність формування активів, ефективність використання активів.
\end{abstract}

Kaminska I., Dorosh V., Kovalchuk A.

\section{METHODICAL APPROACHES TO THE ASSESSMENT OF THE EFFICIENCY OF FORMATION AND USE OF ASSETS OF AN ENTERPRISE}

\begin{abstract}
The modern methodological approaches to complex and systematic evaluation of the efficiency of formation and use of enterprise assets are investigated and improved. The effectiveness of asset formation and utilization is analyzed and evaluated on the example of PJSC «Teremno Khlib».

Keywords: assets of an enterprise, current assets, noncurrent assets, fixed assets, efficiency of formation of assets, efficiency of use of assets.
\end{abstract}

Каминская И.Н., Дорош В.Ю., Ковальчук А.Ю.

\section{МЕТОДИЧЕСКИЕ ПОДХОДЫ К ОЦЕНКЕ ЭФФЕКТИВНОСТИ ФОРМИРОВАНИЯ И ИСПОЛЬЗОВАНИЯ АКТИВОВ ПРЕДПРИЯТИЯ}

В статье исследованы и усовершенствованы современные методические подходы к комплексной и системной оценке эффективности формирования и использования активов предприятия. Проанализировано и осуществлено оценку эффективности формирования и использования активов на примере ОАО «Теремно Хлеб».

Ключевые слова: активы предприятия, оборотные активы, внеоборотные активы, основные средства, эффективность формирования активов, эффективность использования активов.

Постановка проблеми у загальному вигляді i iї зв'язок 3 важливими науковими та практичними завданнями. Комплексне дослідження ефективності формування і використання активів підприємства є об'єктивною необхідністю та важливим інструментом з'ясування сильних і слабких сторін в управлінні ними, що дозволяє визначати можливості та резерви поліпшення поточної ситуації та забезпечення економічного розвитку суб'єкта господарювання. Це зумовлено тим, що від ефективності процесів формування та використання активів загалом залежить ефективність діяльності будь-якого підприємства. Тому, задля досягнення максимально найкращих фінансово-економічних результатів діяльності підприємства та успішного його функціонування на ринку, необхідно систематично відстежувати, аналізувати й проводити оцінку ефективності формування і використання його активів [1, с. 357].

Аналіз останніх досліджень, у яких започатковано вирішення проблеми. Дослідженню теоретичних, методичних і прикладних засад формування та використання активів підприємства присвячені наукові публікації багатьох відомих іноземних і вітчизняних учених, серед яких варто виділити таких, як Базілінська О.Я., Бланк I.А., Білик М.Д., Буряк Л.Д., Срмошенко М.М., Ілляшенко С.М., Ковальов В.В., Коробов М.Я., Крамаренко Г.О., Лисевич С.Г., Люткіна А.В., Майборода О.Є., Мендрул О.Г., Мних Є.В., 
Поддєрьогін А.М., Подольська О.В., Слав’юк Р.А., Скоробогатова В.В., Чернецька С.А., Чемчикаленко Р.А., Шеремет А.Д., Цал-Цалко Ю.С. і багатьох інших. Разом з тим, як показало проведене дослідження зарубіжних та вітчизняних наукових праць 3 питань аналізу ефективності формування та використання активів підприємства, в економічній літературі хоча і наявна значна кількість напрацювань, проте відсутній чіткий i комплексний алгоритм оціночних дій у даному напрямі. Основним чином, вчені акцентують увагу на методичних підходах до аналізу відокремлено певних складових елементів активів підприємства, зосереджуючи увагу або на оборотних активах, або необоротних активах і то здебільшого в частині основних засобів.

Цілі статті. Основними цілями статті є дослідження і вдосконалення методичних підходів до комплексної та системної оцінки ефективності формування і використання активів підприємства.

Виклад основного матеріалу дослідження 3 повним обгрунтуванням отриманих наукових результатів. Оцінка ефективності формування і використання активів є дослідницьким процесом, одним із найважливіших напрямів оцінки фінансовогосподарської діяльності підприємства [2, с. 332], предметом якого є загалом виробничогосподарська діяльність підприємства, як результат формування і використання активів.

Активи підприємства варто розглядати як сукупність матеріальних i нематеріальних цінностей суб' єкта господарювання у вартісному виразі, що формуються 3 власних i позичкових джерел фінансування, систематично поновлюються (відновлюються), обслуговуючи виробничо-господарський процес і забезпечуючи його безперервність задля досягнення економічних і соціальних вигід [3].

Мета оцінки ефективності формування і використання активів підприємства полягає у тому, щоб отримати максимально об'єктивні результати щодо рівня ефективності їх формування і використання, які слугуватимуть вихідною базою пошуку оптимальних та найбільш раціональних шляхів забезпечення економічного розвитку суб'єкта господарювання у коротко- і довгостроковій перспективі. Вказане визначає практичну значимість такої оцінки.

До основних завдань оцінки ефективності формування і використання активів підприємства належать: 1) встановлення достатності сформованих активів для забезпечення безперервного процесу виробництва та досягнення необхідних темпів економічного розвитку підприємства, а також виявлення потреби в залученні додаткових обсягів активів, чи доцільності їх вивільнення; 2) дослідження оптимальності і раціональності сформованої структури й складу активів, напрямів їх розподілу за видами діяльності; 3) дослідження правильності та доцільності вкладення фінансових ресурсів в активи; 4) дослідження ефективності використання активів, встановлення рівня їх віддачі при наявному рівні операційного й фінансового ризику; 5) виявлення ключових факторів позитивного i негативного впливу на ефективність формування та використання активів на підприємстві та причин їх виникнення; 6) ідентифікація і мобілізація резервів підвищення ефективності формування та використання активів; 7) своєчасна реакція керівництва на результати аналітичного дослідження з виявленням і розробкою найбільш доцільних майбутніх шляхів і методів підвищення ефективності формування та використання активів підприємства, нарощення їх вартості, підвищення конкурентоспроможності й інвестиційної привабливості суб'єкта господарювання в цілому. Загалом зазначене дослідження дає змогу вчасно реагувати на несприятливі внутрішні та зовнішні фактори, які заважають нормальному функціонуванню підприємства [4]. При цьому така оцінка повинна здійснюватись через призму як короткострокової, так і довгострокової перспективи розвитку підприємства [5, с. 488].

Інформаційну базу оціночного дослідження повинні становити дані фінансової звітності підприємства, зокрема, форми 1, 2, 3, 4, 5, а також дані аналітичного та 
синтетичного обліку й інша доступна інформація.

Оцінюючи ефективність формування i використання активів підприємства, доцільно керуватись такими принципами, як об'єктивність, своєчасність, системність, комплексність, точність, репрезентативність, зрозумілість і прозорість результатів.

Вдосконалюючи існуючі підходи [5, с. 488-489; 6], вважаємо, алгоритм комплексної оцінки ефективності формування і використання активів підприємства повинен охоплювати систему послідовних дій, яка зображена на рисунку 1.

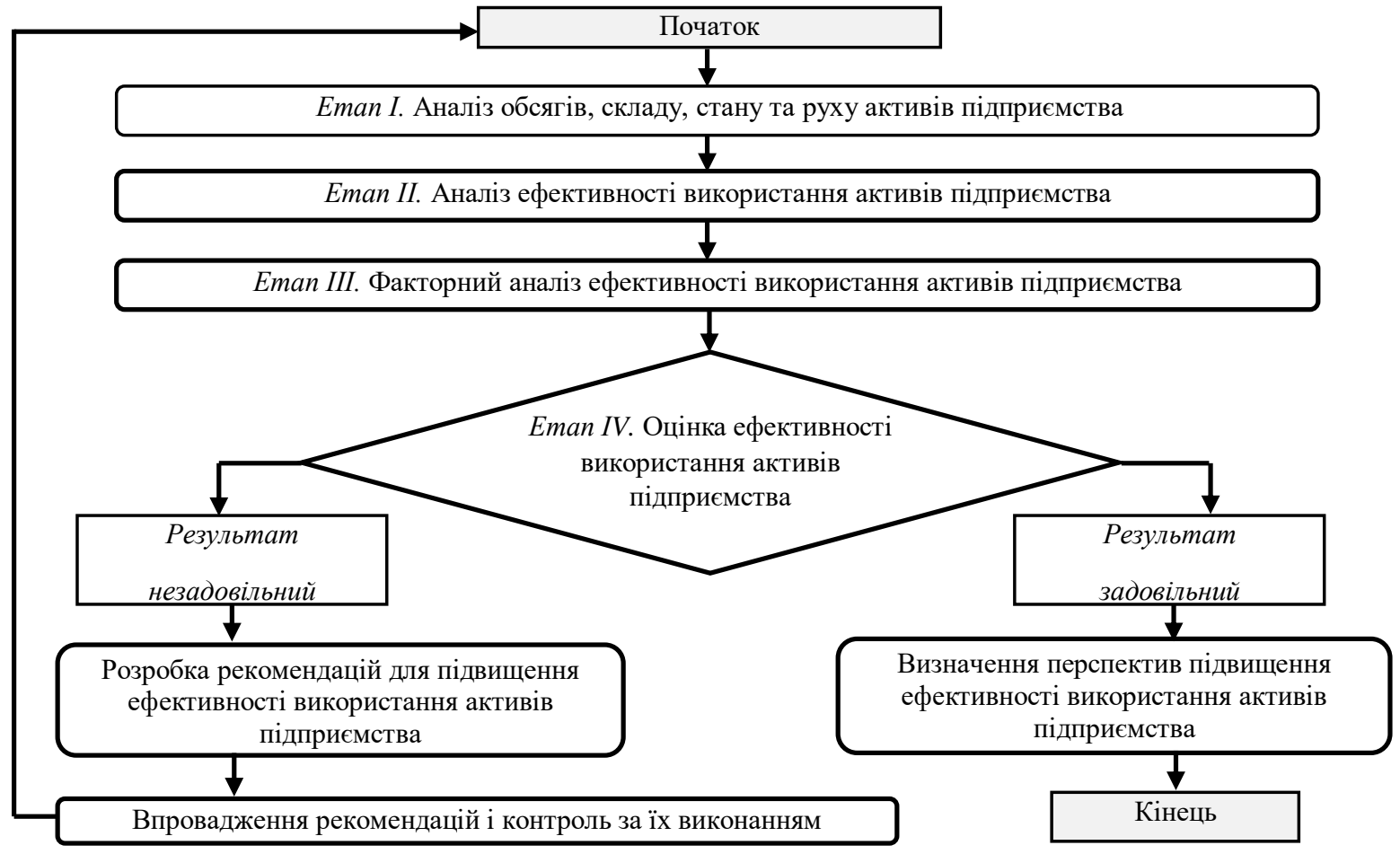

Рис. 1. Алгоритм оцінки ефективності формування i використання активів підприємства

3 метою оцінки ефективності формування та використання активів, дослідники пропонують використовувати безліч аналітичних показників (табл. 1).

Таблиця 1.

Аналітичні показники оцінки ефективності формування та використання активів підприємства [7]

\begin{tabular}{|c|c|c|c|c|c|c|c|}
\hline \multirow[b]{2}{*}{ Показники } & \multicolumn{7}{|c|}{ Автори } \\
\hline & $\begin{array}{l}\text { Буряк } \\
\text { Л.Д. }\end{array}$ & $\begin{array}{l}\text { Крамаренко } \\
\text { Г.О. }\end{array}$ & $\begin{array}{c}\text { Мних } \\
\text { Є.В. }\end{array}$ & $\begin{array}{l}\text { Поддєрьогін } \\
\text { А.М. }\end{array}$ & $\begin{array}{c}\text { Подольська } \\
\text { О.В. }\end{array}$ & $\begin{array}{l}\text { Слав’юк } \\
\text { P.А. }\end{array}$ & \begin{tabular}{|c|} 
Цал-Цалко \\
Ю.С. \\
\end{tabular} \\
\hline $\begin{array}{l}\text { Коефіцієнт співвідношення } \\
\text { оборотних і необоротних активів }\end{array}$ & + & - & - & + & - & + & - \\
\hline Коефіцієнт покриття & - & - & - & - & - & + & - \\
\hline Коефіцієнт зносу & + & + & + & + & + & - & + \\
\hline $\begin{array}{l}\text { Коефіцієнт оборотності } \\
\text { оборотних активів }\end{array}$ & - & + & - & - & - & + & + \\
\hline Коефіцієнт придатності & + & + & + & + & + & - & + \\
\hline Коефіцієнт оновлення & + & + & + & - & + & - & + \\
\hline Коефіцієнт вибуття & + & + & + & - & + & - & + \\
\hline Рентабельність активів & + & - & + & + & - & - & - \\
\hline Фондоозброєність & - & - & - & - & + & - & - \\
\hline Фондовіддача & - & - & - & - & + & - & - \\
\hline
\end{tabular}

Узагальнюючу оцінку ефективності формування та використання активів підприємства вчені пропонують проводити за показником економічної доданої вартості 
(EVA - Economic Value Added), оскільки він [5, с. 487]: 1) відображає економічні показники підприємства загалом із позиції як ефективності вкладення коштів (капіталу), так і правильності використання наявного потенціалу (активів); 2) має високу кореляцію 3 ринковою вартістю підприємства; 3) вирівнює інтереси як акціонерів, так і менеджерів бізнесу; 4) зрозумілий для вітчизняних та зарубіжних інвесторів; 5) є економічним показником, який поєднує витрати на формування активів (операційні витрати) 3 витратами, пов'язаними з володінням капіталом.

Проаналізуємо та проведемо оцінку ефективності формування та використання активів на прикладі ПАТ «Теремно Хліб» (м. Луцьк).

Eтап I. Аналіз обсягів, складу, стану та руху активів підприємства. Проаналізуємо забезпеченість ПАТ «Теремно Хліб» активами, їх видовий склад та динаміку (табл. 2).

Таблиця 2.

Аналіз забезпеченості ПАТ «Теремно Хліб» активами, їх видовий склад і динаміка у 2016-2018 роках

\begin{tabular}{|c|c|c|c|c|c|c|c|}
\hline \multirow{3}{*}{ Активи } & \multirow{3}{*}{2016 p. } & \multirow{3}{*}{2017 p. } & \multirow{3}{*}{2018 p. } & \multicolumn{4}{|c|}{ Відхилення } \\
\hline & & & & \multicolumn{2}{|c|}{ абсолютне } & \multicolumn{2}{|c|}{ відносне, \% } \\
\hline & & & & $\begin{array}{l}2017 \mathrm{p} . / \\
2016 \mathrm{p} .\end{array}$ & $\begin{array}{l}2018 \mathrm{p} . / \\
2017 \text { p. }\end{array}$ & $\begin{array}{l}2017 \text { p./ } \\
2016 \text { p. }\end{array}$ & $\begin{array}{l}2018 \text { p./ } \\
2017 \text { p. }\end{array}$ \\
\hline 1. Необоротні активи & 34169 & 40184 & 83890 & 6015 & 43706 & 17,60 & 108,76 \\
\hline $\begin{array}{l}\text { 1.1. Нематеріальні активи (залишкова } \\
\text { вартість) }\end{array}$ & 79 & 69 & 57 & -10 & -12 & -67 & -2 \\
\hline 1.2. Незавершені капітальні інвестиції & 121 & 2974 & 1007 & 2853 & -1967 & 2357,85 & $-66,14$ \\
\hline 1.3. Основні засоби (залишкова вартість) & 32511 & 37141 & 82826 & 4630 & 45685 & 14,24 & 123,00 \\
\hline 1.4. Інвестиційна нерухомість & 1458 & 0 & 0 & -1458 & 0 & -100 & - \\
\hline 2. Оборотні активи & 18271 & 21753 & 28900 & 3482 & 7147 & 19,06 & 32,86 \\
\hline 2.1. Виробничі запаси & 6388 & 8021 & 10722 & 1633 & 2701 & 25,56 & 33,67 \\
\hline 2.2. Готова продукція & 123 & 146 & 1256 & 23 & 1110 & 18,70 & 760,27 \\
\hline 2.3. Товари & 378 & 272 & 131 & -106 & -141 & -237 & -35 \\
\hline $\begin{array}{l}\text { 2.4. Дебіторська заборгованість за } \\
\text { продукцію }\end{array}$ & 3904 & 7932 & 11829 & 4028 & 3897 & 103,18 & 49,13 \\
\hline $\begin{array}{l}\text { 2.5. Дебіторська заборгованість за } \\
\text { розрахунками з бюджетом }\end{array}$ & 21 & 272 & 8 & 251 & -264 & 1195,24 & $-97,06$ \\
\hline $\begin{array}{l}\text { 2.6. Дебіторська заборгованість за } \\
\text { розрахункам за виданими авансами }\end{array}$ & 4934 & 1711 & 2010 & -3223 & 299 & $-65,32$ & 17,48 \\
\hline $\begin{array}{l}\text { 2.7. Дебіторська заборгованість за } \\
\text { розрахунками із внутрішніх розрахунків }\end{array}$ & 3 & 3 & 3 & 0 & 0 & 0 & 0 \\
\hline $\begin{array}{l}\text { 2.8. Інша поточна дебіторська } \\
\text { заборгованість }\end{array}$ & 995 & 1362 & 930 & 367 & -432 & 36,88 & $-31,72$ \\
\hline 2.9. Готівка & 508 & 1009 & 947 & 501,0 & -62 & 98,62 & $-6,14$ \\
\hline 2.10. Рахунки в банках & 980 & 940 & 982 & -40 & 42 & $-4,08$ & 4,47 \\
\hline 2.11. Інші оборотні активи & 37 & 85,0 & 82,0 & 48 & -3 & 129,73 & $-3,53$ \\
\hline $\begin{array}{l}\text { 3. Необоротні активи, утримувані } \\
\text { для продажу, та групи вибуття }\end{array}$ & 0 & 0 & 0 & 0 & 0 & - & - \\
\hline Всього & 52440 & 61937 & 112800 & 9497 & 50863 & 18,11 & 82,12 \\
\hline
\end{tabular}

Активи підприємства в аналізованому періоді зросли на 18,11\% у 2017 році і на $82,12 \%$ у 2018 році, що засвідчує позитивні зрушення у його роботі. Це було обумовлене підвищенням обсягів як необоротних активів, так і оборотних активів. У складі активів підприємства за обсягами домінували основні засоби, виробничі запаси та дебіторська заборгованість за продукцію. Значні обсяги виробничих запасів і основних засобів негативно впливали на рівень мобільності підприємства. Проте, такий склад і структура активів ПАТ «Теремно Хліб» цілком відображає особливості організації активів суб' єктів господарювання хлібопекарської сфери.

Для детального аналізу активів ПАТ «Теремно Хліб», проаналізуємо 
забезпеченість різноманітними їх видами (табл. 3).

Проведений аналіз дозволяє зробити такі висновки:

1) у складі активів підприємства основні їх обсяги формували необоротні активи, обсяги яких за 2016-2018 роки підвищились у понад 2 рази, тобто досліджуване підприємство розширювало свою матеріально-технічну базу та здійснювало технічне переозброєння. Необоротні активи у структурі активів ПАТ «Теремно Хліб» становили відповідно 65,16\%, 64,88\% і 74,37\% (рис. 2). Очевидно, що зменшення частки оборотних активів у 2018 році негативно вплинуло на показники ліквідності підприємства;

2) обсяги активів у нематеріальній формі були незначними в аналізованому періоді та їх частка у структурі не перевищувала $0,11 \%$. Найбільші обсяги спостерігались активів у матеріальній формі (понад 78\%). Частка фінансових активів зменшилась 3 21,63\% у 2016 році до 14,81\% у 2018 році (рис. 3);

Таблиця 3.

Аналіз забезпеченості ПАТ «Теремно Хліб» різними видами активів

\begin{tabular}{|c|c|c|c|c|c|c|c|}
\hline \multirow[b]{3}{*}{ Різновиди активів } & \multirow[b]{3}{*}{2016 p. } & \multirow[b]{3}{*}{2017 p. } & \multirow[b]{3}{*}{2018 p. } & \multicolumn{4}{|c|}{ Відхилення } \\
\hline & & & & \multicolumn{2}{|c|}{ абсолютне } & \multicolumn{2}{|c|}{ абсолютне } \\
\hline & & & & \begin{tabular}{|c|}
2017 \\
p./ \\
2016 p.
\end{tabular} & $\begin{array}{l}2018 \mathrm{p.} / \\
2017 \mathrm{p} .\end{array}$ & $\left|\begin{array}{c}2017 \mathrm{p.} / \\
2016 \mathrm{p} .\end{array}\right|$ & $\begin{array}{l}2018 \mathrm{p} . \\
2017 \mathrm{p} .\end{array}$ \\
\hline \multicolumn{8}{|c|}{ 1. За економічним змістом } \\
\hline 1.1. Оборотні активи & 18271 & 21753 & 28900 & 3482 & 7147 & 19,06 & 32,86 \\
\hline 1.2. Необоротні активи & 34169 & 40184 & 83890 & 6015 & 43706 & 17,60 & 108,76 \\
\hline \multicolumn{8}{|c|}{ 2. За формою функиііонування } \\
\hline 2.1. Нематеріальні активи & 79 & 69 & 57 & -10 & -12 & $-12,66$ & $-17,39$ \\
\hline 2.2. Матеріальні активи & 41016 & 48639 & 96034 & 7623 & 47395 & 18,59 & 97,44 \\
\hline 2.3. Фінансові активи & 11345 & 13229 & 16709 & 1884 & 3480 & 16,61 & 26,31 \\
\hline \multicolumn{8}{|c|}{ 3. Залежно від методів планування та регулювання } \\
\hline 3.1. Найліквідніші активи & 1488 & 1949 & 1929 & 461 & -20 & 30,98 & $-1,03$ \\
\hline 3.2. Активи, що швидко реалізуються & 9857 & 11280 & 14780 & 1423 & 3500 & 14,44 & 31,03 \\
\hline 3.3. Активи, що повільно реалізуються & 6926 & 8524 & 12191 & 1598 & 3667 & 23,07 & 43,02 \\
\hline 3.4. Активи, що важко реалізуються & 34169 & 40184 & 83900 & 6015 & 43716 & 17,60 & 108,79 \\
\hline \multicolumn{8}{|c|}{ 4. За джерелами формування } \\
\hline $\begin{array}{l}\text { 4.1. Активи сформовані за рахунок власного } \\
\text { капіталу }\end{array}$ & 13628 & 13708 & 59692 & 80 & 45984 & 0,59 & 335,45 \\
\hline $\begin{array}{l}\text { 4.2. Активи сформовані за рахунок } \\
\text { довгострокових зобов'язань і забезпечень }\end{array}$ & 12965 & 617 & 154 & -12348 & -463 & $-95,24$ & $-75,04$ \\
\hline $\begin{array}{l}\text { 4.3. Активи сформовані за рахунок поточних } \\
\text { зобов’язань і забезпечень }\end{array}$ & 25847 & 47612 & 52954 & 21765 & 5342 & 84,21 & 11,22 \\
\hline \multicolumn{8}{|c|}{ 5. За характером фінансових джерел формування } \\
\hline 5.1. Валові активи & 13628 & 13708 & 59692 & 80 & 45984 & 0,59 & 335,45 \\
\hline 5.2. Чисті активи & 38812 & 48229 & 53108 & 9417 & 4879 & 24,26 & 10,12 \\
\hline \multicolumn{8}{|c|}{ 6. За характером участі в різних видах діяльності } \\
\hline 6.1. Операційні активи & 50861 & 58963 & 111783 & 8102 & 52820 & 15,93 & 89,58 \\
\hline 6.2. Інвестиційні активи & 1579 & 2974 & 1017 & 1395 & -1957 & 88,35 & $-65,80$ \\
\hline \multicolumn{8}{|c|}{ 7. Залежно від місия використання } \\
\hline $\begin{array}{l}\text { 7.1. Активи, що використовуються всередині } \\
\text { підприємства }\end{array}$ & 33219 & 41193 & 84837 & 7974 & 43644 & 24,00 & 105,95 \\
\hline $\begin{array}{l}\text { 7.2. Активи, що використовуються за } \\
\text { межами підприємства }\end{array}$ & 19221 & 20744 & 27963 & 1523 & 7219 & 7,92 & 34,80 \\
\hline Всього & 52440 & 61937 & 112800 & 9497 & 50863 & 18,11 & 82,12 \\
\hline
\end{tabular}




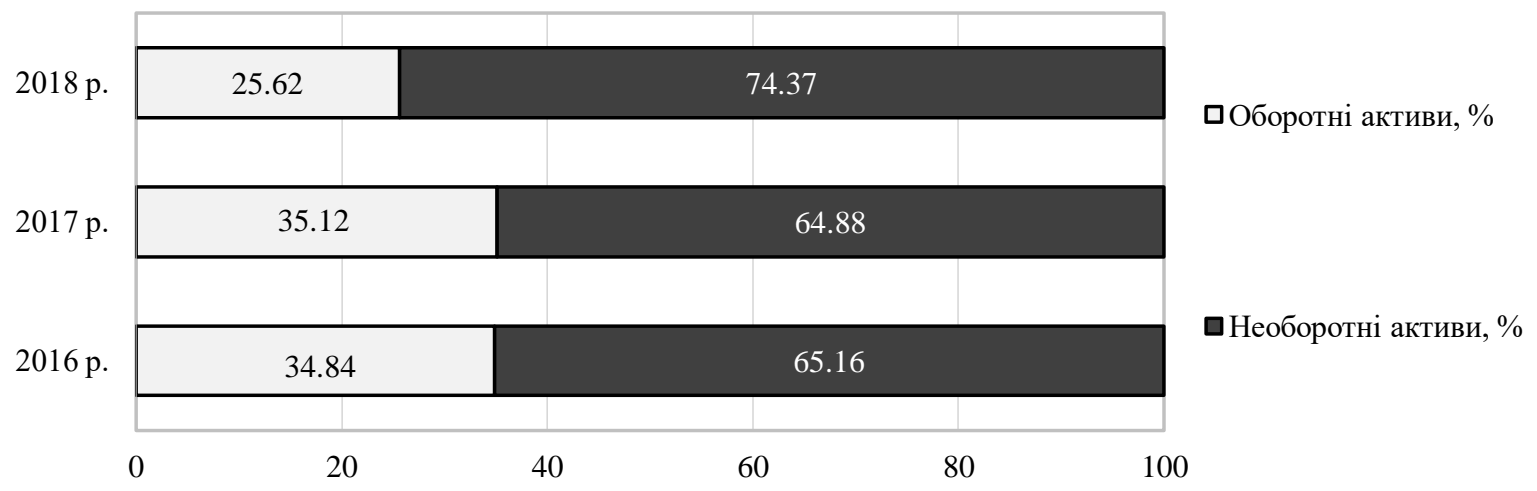

Рис. 2. Структура активів ПАТ «Теремно Хліб» за економічним змістом

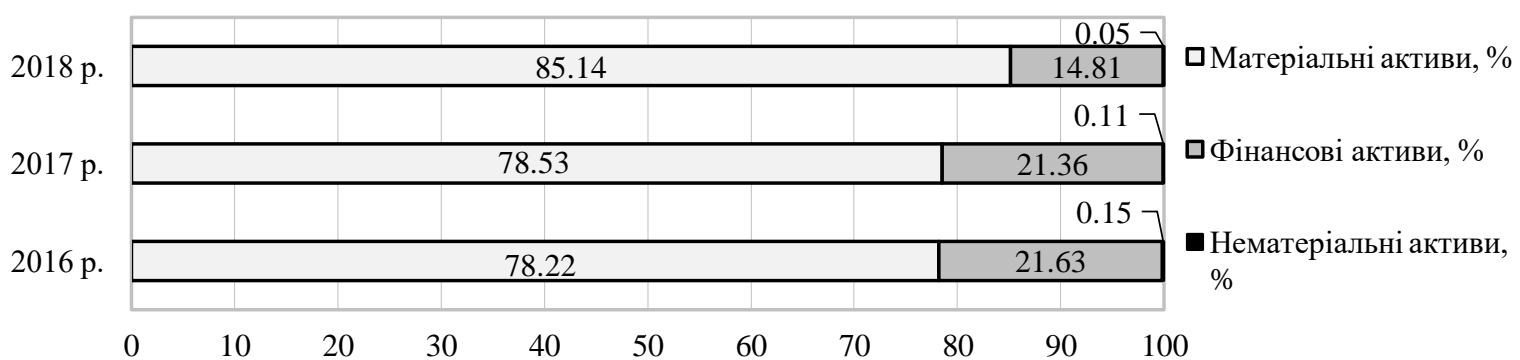

Рис. 3. Структура активів ПАТ «Теремно Хліб» за формою функціонування

3) обсяги найліквідніших активів були найменшими та їх частка у структурі активів становила відповідно 2,84\%, 3,15\% і 1,71\% (рис. 4). Найбільшу частку становили активи, що важко реалізуються.

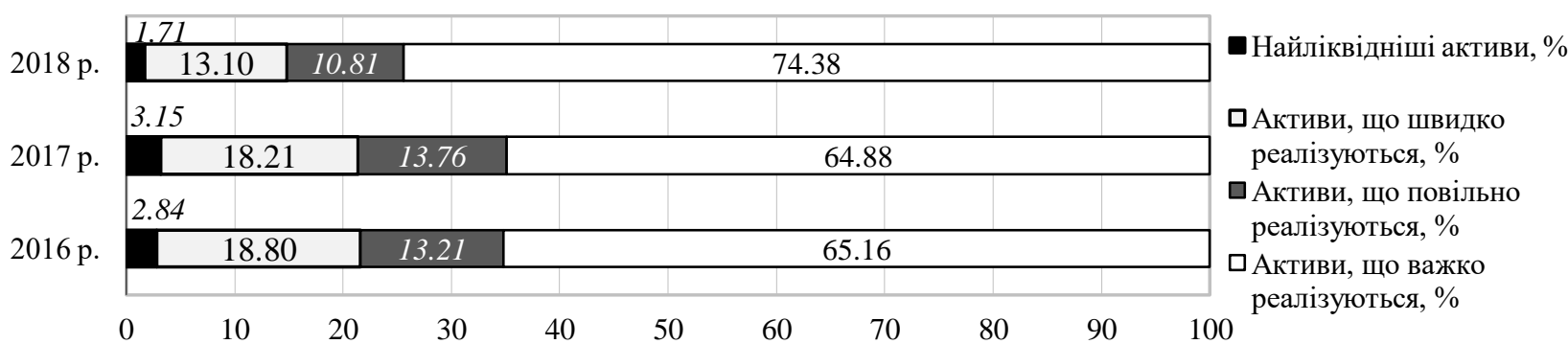

Рис. 4. Структура активів ПАТ «Теремно Хліб» за рівнем ліквідності

Щороку відмічалась недостатність найліквідніших активів (табл. 4). Нестача таких активів теоретично компенсовувалась надлишком активів за іншими групами.

Аналіз ліквідності балансу ПАТ «Теремно Хліб»

\begin{tabular}{|c|c|c|c|c|c|c|c|c|c|c|}
\hline \multirow[t]{2}{*}{ Актив } & \multicolumn{3}{|c|}{ Тис. грн. } & \multirow[t]{2}{*}{ Пасив } & \multicolumn{3}{|c|}{ Тис. грн. } & \multicolumn{3}{|c|}{$\begin{array}{c}\text { Платіжний залишок } \\
\text { (нестача), тис. грн. }\end{array}$} \\
\hline & $2016 \mathrm{p}$. & $2017 \mathrm{p}$. & $2018 \mathrm{p}$. & & $2016 \mathrm{p}$. & $2017 \mathrm{p}$. & $2018 \mathrm{p}$. & 2016 & 2017 & 2018 \\
\hline $\begin{array}{l}\text { Найліквід } \\
\text { активи ( }\end{array}$ & 1488 & 49 & 1929 & ( & 18593 & 32507 & 38637 & -17105 & -30558 & -3670 \\
\hline \begin{tabular}{|c|} 
Активи, що швидко \\
реалізуються (А2) \\
\end{tabular} & 9857 & 11280 & 14780 & $\begin{array}{c}\text { Короткострокові } \\
\text { пасиви (П2) } \\
\end{array}$ & 7254 & 15105 & 14317 & 2603 & -3825 & 463 \\
\hline $\begin{array}{c}\text { Активи, що повільно } \\
\text { реалізуються (А3) }\end{array}$ & 6926 & 8524 & 12191 & $\begin{array}{r}\text { Довге } \\
\text { паси } \\
\end{array}$ & 12965 & 617 & 1 & -6039 & 7907 & 120 \\
\hline $\begin{array}{l}\text { Активи, що важко } \\
\text { реалізуються (A4) }\end{array}$ & 34169 & 40184 & 83900 & $\begin{array}{c}\text { Постійні пасиви } \\
\text { (П4) }\end{array}$ & 13628 & 13708 & 59692 & 20541 & 26476 & 24208 \\
\hline Баланс & 52440 & 61937 & 112800 & Баланс & 52440 & 61937 & 112800 & & - & 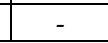 \\
\hline
\end{tabular}

4) у 2018 році у понад 3 рази збільшились обсяги активів, сформованих за рахунок 
власного капіталу та їх обсяги були найбільшими у складі активів підприємства (рис. 5). Така їх динаміка позитивно вплинула на рівень фінансової стійкості підприємства. Активи сформовані за рахунок довгострокових зобов'язань і забезпечень у 2016 році становили 24,72\%, у наступні два роки їх частка зменшилась відповідно до $1,00 \%$ i $0,14 \%$. Активи сформовані за рахунок поточних зобов'язань і забезпечень у 2016 році становили 49,29\%, у 2017 році - 76,87\%, а у 2018 році - 46,95\%;

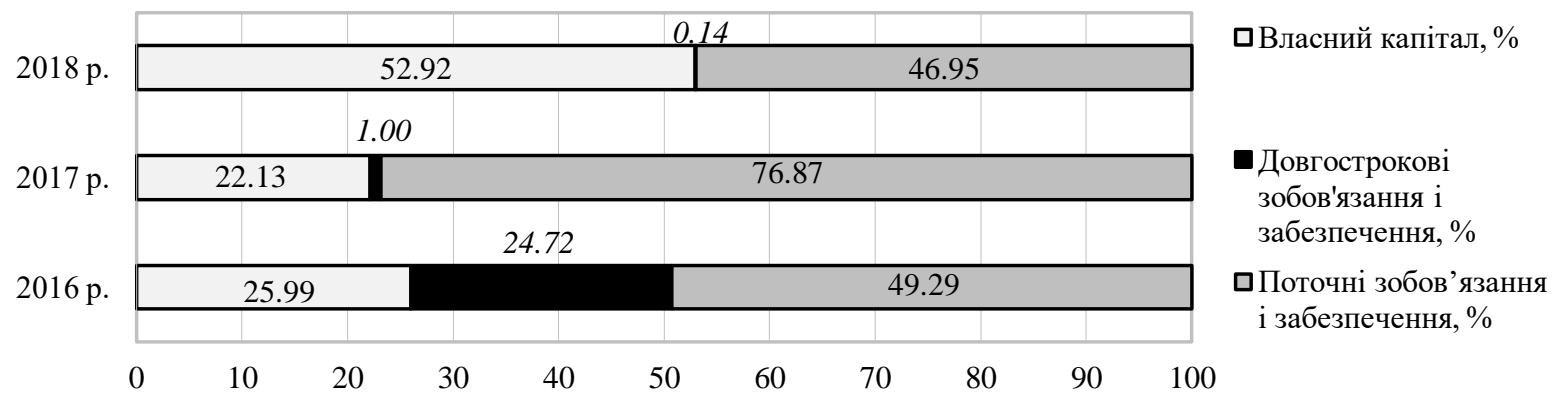

Рис. 5. Структура джерел формування активів ПАТ «Теремно Хліб»

5) обсяги валових активів у 2016 і 2017 роках були у понад 3 рази меншими за обсяги чистих активів, однак у 2018 році вони становили 52,92\% усіх активів (рис. 6);

6) обсяги операційних активів домінували у структурі активів підприємства і за роками становили не менше 95\% (рис. 7);

7) активи, що використовуються всередині підприємства, у досліджуваному періоді зростали й домінували у структурі активів підприємства (рис. 8).

Таким чином, на основі проведеного аналізу забезпеченості ПАТ «Теремно Хліб» активами, їх складу, структури та динаміки, можемо стверджувати, що підприємство недостатньо ефективно їх формує і це негативно впливає на його платоспроможність, ліквідність, майновий і загалом фінансовий стан.

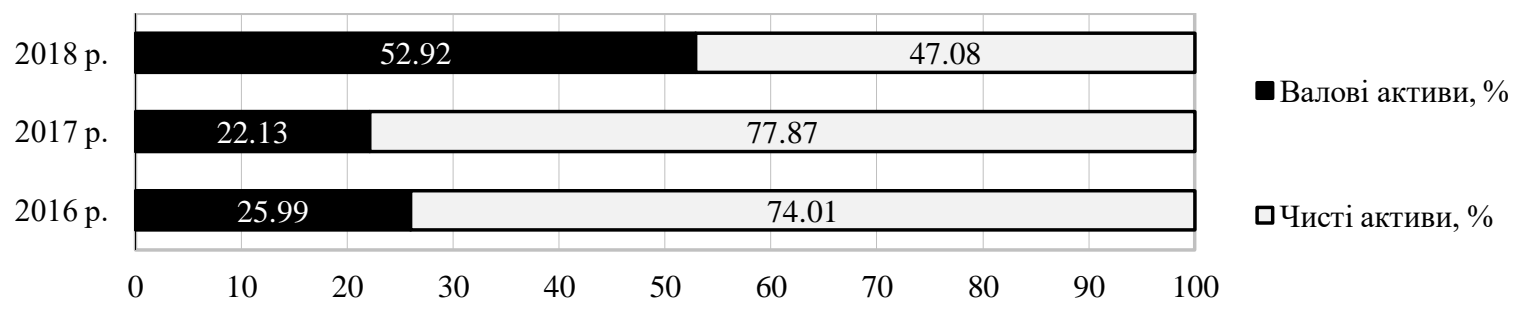

Рис. 6. Структура активів ПАТ «Теремно Хліб» за характером фінансових джерел формування у 2016-2018 роках

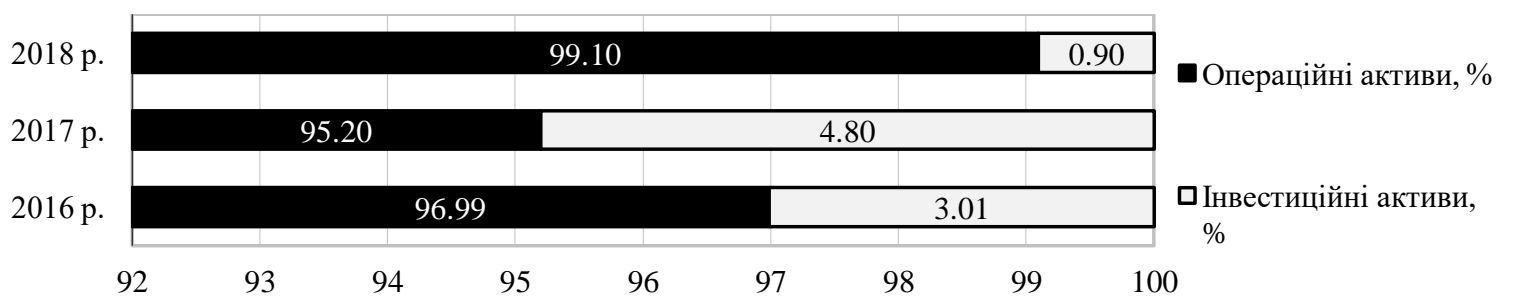

Рис. 7. Структура активів ПАТ «Теремно Хліб» за характером участі в різних видах діяльності у 2016-2018 роках 


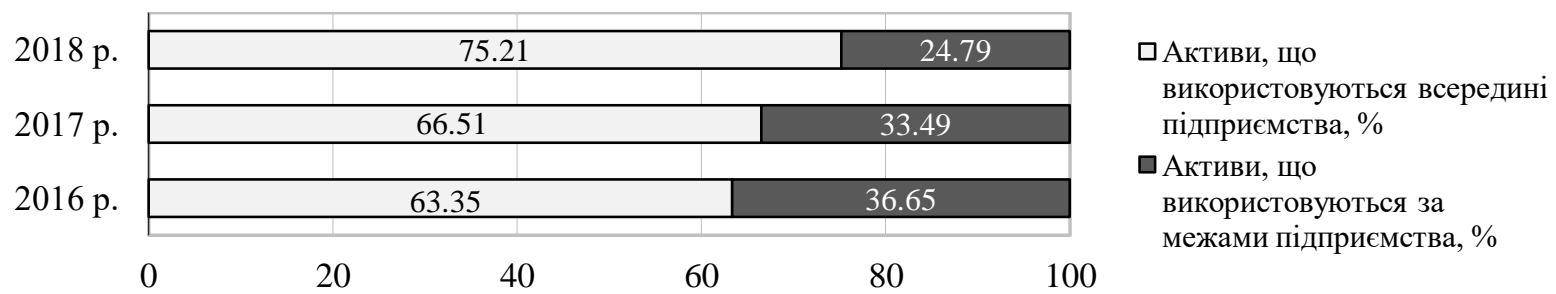

Рис. 8. Структура активів ПАТ «Теремно Хліб» за характером участі в різних видах діяльності у 2016-2018 роках

Eman II. Аналіз ефективності використання активів. Насамперед, проаналізуємо ефективність використання нематеріальних активів ПАТ «Теремно Хліб» (табл. 5).

На основі проаналізованих показників можемо зробити такі висновки щодо ефективності використання нематеріальних активів ПАТ «Теремно Хліб»: 1) залишкова вартість нематеріальних активів щороку зменшувалась; 2) підприємство не нарощувало нематеріальні активи у аналізованому періоді; 3) вибуття нематеріальних активів 3 балансу підприємства відбулось лише у 2018 році; 4) роль нематеріальних активів щороку зменшувалась, адже їх частка у вартості необоротних активів, зокрема, і активів в цілому за роками зменшувалась; 5) рівень зносу нематеріальних активів у 2016 році становив 0,18 , а до 2018 року - підвищився до 0,37 та відповідно рівень їх придатності зменшився з 82\% до 63\% у 2016-2018 роках, що задовольняє рекомендовані значення цих показників; 6) щорічно підвищувався рівень віддачі нематеріальних активів, зокрема, у 2017 році - на 27,32\% і у 2018 році - на 36,32\%; 7) рентабельність нематеріальних активів, розрахована за валовим прибутком динамічно зростала у результаті підвищення обсягів валового прибутку з кожним роком; 8) обсяги чистого прибутку на 1 грн нематеріальних активів у 2017 році зменшились у понад 15 разів, але у 2018 році - підвищилась у понад 50 разів. Таким чином, можна стверджувати про підвищення ефективності використання нематеріальних активів на досліджуваному підприємстві.

Таблиця 5.

Аналіз ефективності використання нематеріальних активів

\begin{tabular}{|c|c|c|c|c|c|c|c|}
\hline \multirow[b]{3}{*}{ Показники } & \multirow[b]{3}{*}{$\begin{array}{c}2016 \\
\text { p. }\end{array}$} & \multirow[b]{3}{*}{$\begin{array}{l}2017 \\
\text { p. }\end{array}$} & \multirow[b]{3}{*}{$\begin{array}{l}2018 \\
\text { p. }\end{array}$} & \multicolumn{4}{|c|}{ Відхилення } \\
\hline & & & & \multicolumn{2}{|c|}{ абсолютне } & \multicolumn{2}{|c|}{ відносне, \% } \\
\hline & & & & $\begin{array}{c}2017 \\
\text { p./ } \\
2016 \mathrm{p} .\end{array}$ & $\begin{array}{l}2018 \mathrm{p} . / \\
2017 \mathrm{p} .\end{array}$ & $\begin{array}{c}2017 \\
\mathrm{p} . / \\
2016 \mathrm{p}\end{array}$ & $2018 \mathrm{p}$. \\
\hline $\begin{array}{l}\text { 1. Залишкова вартість нематеріальних активів, тис. } \\
\text { грн. }\end{array}$ & 79 & 69 & 57 & -10 & -12 & $-12,66$ & $-17,39$ \\
\hline 2. Первісна вартість нематеріальних активів, тис. грн. & 96 & 96 & 90 & 0 & -6 & 0,00 & $-6,25$ \\
\hline 3. Знос, тис. грн. & 17 & 27 & 33 & 10 & 6 & 58,82 & 22,22 \\
\hline $\begin{array}{l}\text { 4. Питома вага нематеріальних активів у необоротних } \\
\text { активах, } \%\end{array}$ & 0,23 & 0,17 & 0,07 & $-0,06$ & $-0,10$ & $-25,73$ & $-60,43$ \\
\hline 5. Питома вага нематеріальних активів у активах, \% & 0,15 & 0,11 & 0,05 & $-0,04$ & $-0,06$ & $-26,05$ & $-54,64$ \\
\hline 6. Введено нематеріальних активів, тис. грн. & 0 & 0 & 0 & 0 & 0 & - & - \\
\hline 7. Виведено нематеріальних активів, тис. грн. & 0 & 0 & 6 & 0 & 6 & - & - \\
\hline 8. Коефіцієнт зносу нематеріальних активів (п.3/п.2) & 0,18 & 0,28 & 0,37 & 0,10 & 0,09 & 58,82 & 30,37 \\
\hline $\begin{array}{l}\text { 9. Коефіцієнт придатності нематеріальних активів } \\
(\text { п.1/п.2) }\end{array}$ & 0,82 & 0,72 & 0,63 & $-0,10$ & $-0,09$ & $-12,66$ & $-11,88$ \\
\hline 10. Коефіцієнт виведення нематеріальних активів & 0,00 & 0,00 & 0,11 & 0,00 & 0,11 & - & - \\
\hline 11. Віддача нематеріальних активів, грн./грн. & 2312 & 2943 & 4013 & 631 & 1069 & 27,32 & 36,32 \\
\hline $\begin{array}{l}\text { 12. Валовий прибуток на } 1 \text { грн нематеріальних } \\
\text { активів, грн. }\end{array}$ & 808 & 1176 & 1589 & 368 & 414 & 45,54 & 35,20 \\
\hline $\begin{array}{l}\text { 13. Чистий прибуток на } 1 \text { грн нематеріальних активів, } \\
\text { грн. }\end{array}$ & 17,6 & 1,15 & 59,7 & $-16,44$ & 58,54 & 93,41 & 5090 \\
\hline
\end{tabular}


Іншим елементом необоротних активів підприємства є основні засоби. Зупинимось на аналізі ефективності їх використання (табл. 6).

Таблиця 6. Аналіз ефективності використання основних засобів ПАТ «Теремно Хліб» у 2016-2018

\begin{tabular}{|c|c|c|c|c|c|c|c|}
\hline \multicolumn{8}{|c|}{ роках } \\
\hline \multirow{3}{*}{ Показники } & \multirow{3}{*}{$2016 \mathrm{p}$. } & \multirow{3}{*}{$2017 \mathrm{p}$} & \multirow{3}{*}{$2018 \mathrm{p}$} & \multicolumn{4}{|c|}{ Відхилення } \\
\hline & & & & \multicolumn{2}{|c|}{ абсолютне } & \multicolumn{2}{|c|}{ відносне, \% } \\
\hline & & & & $\begin{array}{l}2017 \text { p./ } \\
2016 \text { p. }\end{array}$ & $\begin{array}{l}2018 \mathrm{p} . / \\
2017 \mathrm{p} .\end{array}$ & $\begin{array}{l}2017 \mathrm{p} . / \\
2016 \mathrm{p} .\end{array}$ & $\begin{array}{l}2018 \mathrm{p} . / \\
2017 \mathrm{p} .\end{array}$ \\
\hline 1. Залишкова вартість основних засобів, тис. грн. & 32511 & 37141 & 82826 & 4630 & 45685 & 14,24 & 123,00 \\
\hline 2. Первісна вартість основних засобів, тис. грн. & 71811 & 72445 & 219324 & 634 & 146879 & 0,88 & 202,75 \\
\hline 3. Знос, тис. грн. & 39300 & 35304 & 136498 & -3996 & 101194 & $-10,17$ & 286,64 \\
\hline $\begin{array}{l}\text { 4. Питома вага основних засобів у необоротних } \\
\text { активах, \% }\end{array}$ & 95,15 & 92,43 & 98,73 & $-2,72$ & 6,30 & - & - \\
\hline 5. Питома вага основних засобів у активах, \% & 62,00 & 59,97 & 73,43 & $-2,03$ & 13,46 & - & - \\
\hline $\begin{array}{l}\text { 6. Залишкова вартість активної частини основних } \\
\text { засобів, тис. грн. }\end{array}$ & 15338 & 18025 & 57846 & 2687 & 39821 & 17,52 & 220,92 \\
\hline $\begin{array}{l}\text { 7. Питома вага активної частини основних засобів у } \\
\text { вартості основних засобів, \% }\end{array}$ & 47,18 & 48,53 & 69,84 & 1,35 & 21,31 & - & - \\
\hline $\begin{array}{l}\text { 8. Залишкова вартість пасивної частини основних } \\
\text { засобів, тис. грн. }\end{array}$ & 17173 & 19116 & 24980 & 1943 & 5864 & 11,31 & 30,68 \\
\hline $\begin{array}{l}\text { 9. Питома вага пасивної частини основних засобів у } \\
\text { вартості основних засобів, \% }\end{array}$ & 52,82 & 51,47 & 30,16 & $-1,35$ & $-21,31$ & - & - \\
\hline 10. Вартість введених основних засобів, тис. грн. & 2719 & 14406 & 159280 & 11687 & 144874 & 429,83 & 1005 \\
\hline 11. Вартість основних засобів, що вибули, тис. грн. & 541 & 393 & 1692 & -148 & 1299 & $-27,36$ & 330,53 \\
\hline 12. Коефіцієнт зносу основних засобів (п.3/п.2) & 0,55 & 0,49 & 0,62 & $-0,06$ & 0,14 & $-10,95$ & 27,71 \\
\hline 13. Коефіцієнт придатності основних засобів (п.1/п.2) & 0,45 & 0,51 & 0,38 & 0,06 & $-0,14$ & 13,24 & $-26,34$ \\
\hline 14. Коефіцієнт введення основних засобів & 0,08 & 0,39 & 1,92 & 0,30 & 1,54 & 363,78 & 395,80 \\
\hline 15. Коефіцієнт вибуття основних засобів & 0,02 & 0,01 & 0,02 & $-0,01$ & 0,01 & $-36,41$ & 93,06 \\
\hline 16. Фондоозброєність, тис. грн./особу & 65,28 & 74,58 & 167,66 & 9,30 & 93,08 & 14,24 & 124,81 \\
\hline 17. Техноозброєність, тис. грн./особу & 30,80 & 36,19 & 117,10 & 5,40 & 80,90 & 17,52 & 223,52 \\
\hline 18. Фондовіддача основних засобів, грн./грн. & 5,62 & 5,47 & 2,76 & $-0,15$ & $-2,71$ & $-2,66$ & $-49,50$ \\
\hline 19. Фондомісткість, грн./грн. & 0,18 & 0,18 & 0,36 & 0,00 & 0,18 & 2,73 & 98,03 \\
\hline $\begin{array}{l}\text { 20. Фондовіддача активної частини основних засобів, } \\
\text { грн./грн. }\end{array}$ & 11,91 & 11,27 & 3,95 & $-0,64$ & $-7,31$ & $-5,37$ & $-64,91$ \\
\hline $\begin{array}{l}\text { 21. Рентабельність основних засобів за валовим } \\
\text { прибутком, \% }\end{array}$ & 196,39 & 218,49 & 109,40 & 22,09 & $-109,08$ & - & - \\
\hline $\begin{array}{l}\text { 22. Рентабельність основних засобів за чистим } \\
\text { прибутком, \% }\end{array}$ & 4,28 & 0,22 & 4,11 & $-4,06$ & 3,89 & - & - \\
\hline
\end{tabular}

Слідують такі висновки: 1) у 2016-2018 роках підприємство наростило обсяги основних засобів на 14,24\% і 123\% відповідно; 2) основні засоби формували основну частину необоротних активів підприємства (понад 92\%); 3) питома вага основних засобів у вартості активів підприємства у 2016 році становила 62,00\%, а у 2018 році підвищилась до $73,43 \%$; 4) питома вага активної частини основних засобів за роками збільшувалась, тобто їх структура була прогресивною; 5) щороку вводилось основних засобів більше, а ніж виводилось; 6) зношеність основних засобів у 2016 році становила $55 \%$, у 2017 році - 49\%, а у 2018 році - 62\%, тому рівень їх придатності відповідно за роками становив 45\%, 51\% і 38\%; 6) фондовіддача основних засобів підприємства за роками знижувалась (рис. 10), а фондомісткість підвищувалась, тобто з кожним роком ПАТ «Теремно Хліб» вкладало більше коштів на основні засоби задля виробництва певного обсягу продукції; 7) фондовіддача активної частини основних засобів за роками також зменшувалась; 8) рентабельність основних засобів, розрахована за валовим прибутком, у 2016-2018 роках становила відповідно 196,39\%, 218,49\% і 109,40\%; 9) рентабельність основних засобів, розрахована за чистим прибутком, у 2016 році дорівнювала 4,28\%, у 2017 році зменшилась на 4,06\%, а у 2018 році - підвищилась на 3,89\%. Так, згідно проведеного аналізу, можна стверджувати про те, що у товариства «Теремно Хліб» ефективність використання основних засобів знижувалась в 
досліджуваному періоді та для підприємства нагальною є потреба оновлення своєї матеріально-технічної бази, високий рівень зношеності якої унеможливлює максимізацію кінцевих результатів.

Проаналізуємо ефективність використання оборотних активів ПАТ «Теремно Хліб» у 2016-2018 роках за показниками, наведеними в таблиці 7.

Таблиця 7. Аналіз ефективності використання оборотних активів ПАТ «Теремно Хліб» 2016-2018

\begin{tabular}{|c|c|c|c|c|c|c|c|}
\hline \multirow[b]{4}{*}{ Показники } & \multicolumn{7}{|l|}{ роках } \\
\hline & \multirow[b]{3}{*}{$2016 \mathrm{p}}$. & \multirow[b]{3}{*}{$2017 \mathrm{p}}$. & \multirow[b]{3}{*}{$2018 \mathrm{p}$} & \multicolumn{4}{|c|}{ Відхилення } \\
\hline & & & & \multicolumn{2}{|c|}{ абсолютне, $(+/-)$} & \multicolumn{2}{|c|}{ відносне, \% } \\
\hline & & & & $\begin{array}{l}2017 \text { p./ } \\
2016 \text { p. }\end{array}$ & $\begin{array}{c}2018 \\
\text { p./ } \\
2017 \text { p. }\end{array}$ & $\begin{array}{l}2017 \mathrm{p} . / \\
2016 \mathrm{p} .\end{array}$ & $\begin{array}{c}2018 \\
\text { p./ } \\
2017 \mathrm{p} .\end{array}$ \\
\hline 1. Обсяг реалізованої продукції, тис. грн. & 182654 & 203123 & 228742 & 20469 & 25619 & 11,21 & 12,61 \\
\hline 2. Собівартість реалізованої продукції, тис. грн. & 118805 & 121975 & 138129 & 3170 & 16154 & 2,67 & 13,24 \\
\hline 3. Середній залишок оборотних активів, тис. грн. & 22050 & 20012 & 25327 & -2038 & 5315 & $-9,24$ & 26,56 \\
\hline 4. Кількість днів періоду, що аналізується & 360 & 360 & 360 & 0 & 0 & - & - \\
\hline 5. Середній залишок запасів, тис. грн. & 6514 & 7664 & 10274 & 1150 & 2610 & 17,65 & 34,06 \\
\hline 6. Чистий прибуток, тис. грн. & 1391 & 80 & 3403 & -1311 & 3323 & $-94,25$ & 4153 \\
\hline $\begin{array}{l}\text { 7. Середній залишок дебіторської заборгованості за } \\
\text { товари, роботи, послуги, тис. грн. }\end{array}$ & 7873 & 5918 & 9881 & -1955 & 3963 & $-24,83$ & 66,96 \\
\hline $\begin{array}{l}\text { 8. Коефіцієнт оборотності оборотних активів, } \\
\text { обертів (п.1/п.3) }\end{array}$ & 8,28 & 10,15 & 9,03 & 1,87 & $-1,12$ & 22,53 & $-11,02$ \\
\hline $\begin{array}{l}\text { 9. Тривалість одного обороту оборотних активів, } \\
\text { днів (п.4/п.8) }\end{array}$ & 43,46 & 35,47 & 39,86 & $-7,99$ & 4,39 & $-18,39$ & 12,38 \\
\hline $\begin{array}{l}\text { 10. Коефіцієнт завантаження оборотних активів } \\
(1 / \text { п.8) }\end{array}$ & 0,12 & 0,10 & 0,11 & $-0,02$ & 0,01 & $-18,39$ & 12,38 \\
\hline $\begin{array}{l}\text { 11. Рентабельність (+), збитковість (-) оборотних } \\
\text { активів за чистим прибутком, \% (п.6/п.3×100) }\end{array}$ & 6,31 & 0,40 & 13,44 & $-5,91$ & 13,04 & - & - \\
\hline $\begin{array}{l}\text { 12. Коефіцієнт оборотності запасів, обертів } \\
(\text { п.2/п.5) }\end{array}$ & 18,24 & 15,92 & 13,44 & $-2,32$ & $-2,47$ & $-12,74$ & $-15,52$ \\
\hline $\begin{array}{l}\text { 13. Тривалість одного обороту запасів, днів } \\
\text { (п.4/п.12) }\end{array}$ & 19,74 & 22,62 & 26,78 & 2,88 & 4,16 & 14,60 & 18,38 \\
\hline $\begin{array}{l}\text { 14. Коефіцієнт оборотності дебіторської } \\
\text { заборгованості за товари, роботи, послуги, обертів } \\
\text { (п.1/п.7.) }\end{array}$ & 23,20 & 34,32 & 23,15 & 11,12 & $-11,17$ & 47,94 & $-32,55$ \\
\hline $\begin{array}{l}\text { 15. Тривалість одного обороту дебіторської } \\
\text { заборгованості, днів (п.4/п.14) }\end{array}$ & 15,52 & 10,49 & 15,55 & $-5,03$ & 5,06 & $-32,41$ & 48,26 \\
\hline $\begin{array}{l}\text { 16. Тривалість операційного циклу, днів } \\
(\text { п.13+п.15) }\end{array}$ & 35,26 & 33,11 & 42,33 & $-2,15$ & 9,22 & $-6,09$ & 27,84 \\
\hline 17. Власний оборотний капітал, тис. грн. & 58 & 327 & 2 & 269 & -325 & 463,79 & $-99,39$ \\
\hline $\begin{array}{l}\text { 18. Співвідношення клієнтської дебіторської і } \\
\text { кредиторської заборгованостей }\end{array}$ & 0,28 & 0,31 & 0,45 & 0,03 & 0,14 & 9,80 & 46,12 \\
\hline $\begin{array}{l}\text { 19. Приріст прибутку за рахунок зміни оборотності } \\
\text { оборотних активів, тис. грн. }\end{array}$ & 115 & 313 & -9 & 198 & -322 & 172,53 & $-102,81$ \\
\hline
\end{tabular}

Результати проведеного аналізу засвідчили: 1) пришвидшення оборотності оборотних активів у 2017 році на 22,53\% та сповільнення у 2018 році на $11,02 \%$; 2) тривалість одного обороту оборотних активів у 2017 році зменшилась на 7,99 днів (-18,39\%), а у 2018 році - підвищилась на 4,39 днів (+12,38\%); 3) для одержання 1 грн виручки витрачалось у 2016 році 12 коп. оборотних активів, у 2017 році - 10 коп., а у 2018 році - 11 коп., як показав коефіцієнт завантаження оборотних активів; 4) сповільнення оборотності запасів у 2017 році на 12,74\% та іiі у 2018 році - ще на $15,52 \%$; 5) пришвидшення оборотності дебіторської заборгованості за товари, роботи, послуги у 2017 році на 47,94\% та iї сповільнення у 2018 році на 32,55\%, а тому відповідно тривалість одного іiі обороту у 2017 році зменшилась на 5,03 дні $(-32,41 \%)$, а у 2018 році - підвищилась на 5,06 днів $(+48,26 \%) ; 6)$ скорочення тривалості операційного циклу на 2,15 днів (-6,09\%) у 2017 році та його збільшення на 9,22 дні $(+27,84 \%)$ у 2018 році; 
7) зменшення рівня рентабельності оборотних активів у 2016 році на 5,91\% та його підвищення на 13,04\% у 2018 році; 8) у 2016-2018 роках на 1 грн оборотних активів припадало відповідно 6,31 коп., 0,40 коп. і 13,44 коп. чистого прибутку; 9) достатність власного оборотного капіталу в аналізованому періоді; 10) прискорення оборотності оборотних активів у 2016 і 2017 роках, що спричинило приріст прибутку відповідно в сумі 115 тис. грн і 313 тис. грн., проте, у 2018 році сповільнення оборотності оборотних активів викликало зменшення суми прибутку підприємства на 9 тис. грн. Отже, загалом ПАТ «Теремно Хліб» найефективніше використовувало оборотні активи у 2017 році.

Eтап III. Факторний аналіз ефективності використання активів підприємства. 3'ясуємо причини динаміки розглянутих основних показників ефективності використання активів ПАТ «Теремно Хліб», здійснивши факторний їх аналіз (табл. 8).

Таблиця 8.

Результати факторного аналізу основних показників ефективності використання активів

\begin{tabular}{|c|c|c|c|}
\hline \multirow[b]{2}{*}{ Результуючі показники } & \multirow[b]{2}{*}{ Фактори впливу } & \multicolumn{2}{|c|}{ Рівень впливу факторів } \\
\hline & & $\begin{array}{c}2017 \text { p./ } 2016 \\
\text { p. }\end{array}$ & $\begin{array}{c}2018 \text { p./ } 2017 \\
\text { p. }\end{array}$ \\
\hline \multirow{2}{*}{$\begin{array}{c}\text { Віддача нематеріальних } \\
\text { активів, грн./грн. }\end{array}$} & Обсяг реалізованої продукції & 259,10 & 371,29 \\
\hline & $\begin{array}{l}\text { Залишкова вартість нематеріальних } \\
\text { активів }\end{array}$ & 372,63 & 697,92 \\
\hline \multirow{2}{*}{$\begin{array}{c}\text { Віддача основних засобів, } \\
\text { грн./грн. }\end{array}$} & Обсяг реалізованої продукції & 0,63 & 0,69 \\
\hline & Залишкова вартість основних засобів & $-0,78$ & $-3,40$ \\
\hline \multirow{2}{*}{$\begin{array}{l}\text { Коефіцієнт оборотності } \\
\text { оборотних активів }\end{array}$} & Обсяг реалізованої продукції & 0,93 & 1,28 \\
\hline & Середній залишок оборотних активів & 0,94 & $-2,40$ \\
\hline
\end{tabular}

Eman IV. Оиінка ефективності формування та використання активів. У таблиці 9 проаналізовано результати функціонування ПАТ «Теремно Хліб» у 2016-2018 роках на відповідність «золотому правилу» економіки підприємства, яке диктує умови підвищення ефективності використання фінансових ресурсів, вкладених у активи. Лише у 2016 році підприємство функціонувало дотримуючись всіх вимог «золотого правила» економіки, адже темпи росту його прибутку перевищували темпи росту обсягів реалізації продукції, які в свою чергу перевищували темпи росту активів.

Таблиця 9.

Аналіз функціонування ПАТ «Теремно Хліб» на відповідність «золотому правилу» економіки підприємства

\begin{tabular}{|c|c|c|c|c|c|}
\hline \multirow[b]{2}{*}{ Показник } & \multirow[b]{2}{*}{2016 рік } & \multirow[b]{2}{*}{2017 рік } & \multirow[b]{2}{*}{2018 рік } & \multicolumn{2}{|c|}{ Зміна, \% } \\
\hline & & & & \begin{tabular}{|l|}
2017 p./ \\
2016 p.
\end{tabular} & $\begin{array}{l}2018 \mathrm{p} . / \\
2017 \mathrm{p} .\end{array}$ \\
\hline Темп зростання прибутків $\left(\mathrm{T}_{1}\right)$ & 389,64 & 5,75 & 4253,75 & $-383,88$ & 4248,00 \\
\hline $\begin{array}{l}\text { Темп зростання обсягів реалізації } \\
\text { продукції }\left(\mathrm{T}_{2}\right)\end{array}$ & 118,18 & 111,21 & 112,61 & $-6,98$ & 1,41 \\
\hline Темп зростання активів $\left(\mathrm{T}_{3}\right)$ & 112,87 & 118,11 & 182,12 & 5,24 & 64,01 \\
\hline $\begin{array}{c}\text { «Злоте правило» економіки } \\
\text { підприємства: } T_{1}>T_{2}>T_{3}\end{array}$ & \begin{tabular}{|} 
Дотримання \\
всіх умов
\end{tabular} & $\begin{array}{c}\text { Недотриманн } \\
\text { я умов }\end{array}$ & $\begin{array}{c}\text { Дотримання лише } \\
\text { однієї умови: } T_{1}> \\
T_{2} \\
\end{array}$ & - & - \\
\hline
\end{tabular}

3 метою узагальнення проведеного аналізу й інтегральної оцінки ефективності використання активів ПАТ «Теремно Хліб», розрахуємо показник економічної доданої вартості (EVA) у таблиці 10.

Динаміка розрахункового показника EVA та його співвідношення щодо обсягу активів ПАТ «Теремно Хліб» відображено на рисунку 9. 
Розрахунок EVA (за методикою Терещенко О.О., Стецько М.В. [8])

\begin{tabular}{|c|c|c|c|c|c|}
\hline \multirow[b]{2}{*}{ Показники } & \multirow[b]{2}{*}{$2016 \mathrm{p}}$. & \multirow[b]{2}{*}{$2017 \mathrm{p}}$. & \multirow[b]{2}{*}{2018 p. } & \multicolumn{2}{|c|}{ \% приросту } \\
\hline & & & & $\begin{array}{l}2017 \text { p./ } \\
2016 \text { p. }\end{array}$ & $\begin{array}{l}2018 \text { p./ } \\
2017 \text { p. }\end{array}$ \\
\hline Чистий дохід від реалізації продукції (ЧД) & 182654 & 203123 & 228742 & 11,21 & 12,61 \\
\hline Собівартість реалізованої продукції(СВ) & 118805 & 121975 & 138129 & 2,67 & 13,24 \\
\hline Інші витрати (IB) & 20 & 3467 & 535 & 17235 & $-84,57$ \\
\hline Інші операційні витрати (IOB) & 6319 & 6051 & 3862 & $-4,24$ & $-36,18$ \\
\hline Інші операційні доходи (ІОД) & 3565 & 6750 & 3911 & 89,34 & $-42,06$ \\
\hline Необоротні активи без фінансових інвестицій (НА) & 34169 & 40184 & 83890 & 17,60 & 108,76 \\
\hline Довгострокові зобов'язання (безоплатні) (ДЗ) & 1412 & 1188 & 0 & $-15,86$ & $-100,00$ \\
\hline Робочий капітал або власні оборотні кошти (ВОК) & -20541 & -26476 & -24198 & 28,89 & $-8,60$ \\
\hline$E V A=($ ЧД $-C B-I B-I O B+I O Д)-(H A-Д 3+B O K) \times W A C C$ & 55179 & 71361 & 75027 & 29,33 & 5,14 \\
\hline
\end{tabular}

150000

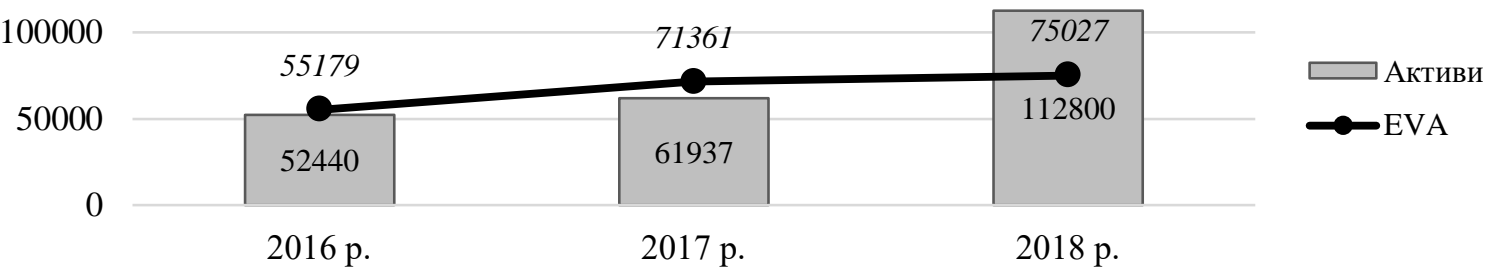

Рис. 9. Динаміка та співвідношення розрахункового показника EVA з обсягами активів ПАТ «Теремно Хліб»

Показник EVA у досліджуваному періоді підвищувався, зокрема, на 29,33\% у 2017 році та на 5,14\% у 2018 році. Позитивна динаміка даного показника дозволяє зробити узагальнюючий висновок про загальну ефективність використання активів на досліджуваному підприємстві та водночас сповільнення темпів іï росту в 2018 році. У 2018 році показник EVA, на жаль, був меншим за обсяги активів підприємства.

Висновки. Отже, проведене дослідження дозволило удосконалити методичні підходи до оцінки ефективності використання оборотних активів підприємства, що слугують важливим інструментом забезпечення ефективного управління ними в поточному періоді й досягнення вигід у майбутньому.

\section{Список бібліографічного опису:}

1. Каціман С.О., Шаманська О.І. Вдосконалення системи управління активами підприємства. Глобальні та наиіональні проблеми економіки. 2017. Вип. 20. C. $357-361$.

2. Чернецька С.А. Аналіз активів підприємства. Вісник Чернівецького торговельно-економічного інститvтv. Економічні науки. 2013. Вип. 3. С. 332336. URL: http://chtei-knteu.cv.ua/herald_en/content/download/archive/2013/v3/NV-2013-V3_59.pdf (дата звернення 15.04.2019).

3. Камінська І.М., Дорош В.Ю., Ковальчук А.Ю. Активи підприємства: морфологічний аналіз категорії, склад та класифікація // Економічний форум : науковий журнал - 2019 - № 3. - C. 136-143. - Режим доступу : http///lutsk-ntu.com ua/sites/default/files/ekonomichniy_forum_vipusk_no32019_2 pdf (дат)

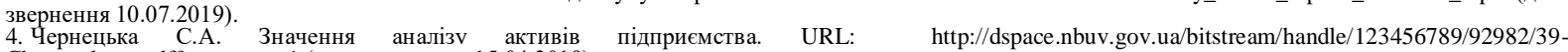
Chernetskaya.pdf?sequence=1 (дата звернення 15.04.2019).

5. Чемчикапенко Р.А., Майборода О.Є. Люткіна А.В. Оцінка ефективності управління активами та пасивами підприємства. Економіка $і$ суспільство. 2017. Вип. №11. C. 485-489. URL: http://www.economyandsociety.in.ua/journal/11_ukr/78.pdf (дата звернення 15.04.2019).

6. Базілінська О.Я. Фінансовии аналіз: теорія та практика: навч. посіб. Київ: Центр учбової літератури, 2009. 328 с.

7. Лисевич С.Г., Д'яченко К.О. Оцінка стану активів підприємства та управління ними. Наукові праці Полтавської державної аграрної академії: Серія: Економічні науки. 2013. 1 (6). C. 206-210. URL: https://www.pdaa.edu.ua/sites/default/files/nppdaa/6.2/206.pdf (дата звернення 15.04.2019).

8. Терещенко О.О., Стецько М.В. Системи показників у концепції фінансового контролінгу у сфері бізнесу. Фінанси України. 2013. № 11. С. 66-83.

\section{References:}

1. Katsiman, S. O., Shamanska, O. I. (2017). Vdoskonalennia systemy upravlinnia aktyvamy pidpryiemstva [Improvement of the system of management of activities of the enterprise]. Hlobalni ta natsionalni problemy ekonomiky - Global and National Problems of Economics, 20, 357-361. [in Ukrainian].

2. Chernetska, S. A. (2013). Analiz aktyviv pidpryiemstva [Analysis of enterprise assets]. Visnyk Chernivetskoho torhovelno-ekonomichnoho instytutu. Ekonomichni nauky - Bulletin of Chernivtsi Trade and Economics Institute. Economics, 3, 332-336. Retrieved from http://chtei.

Estots of an enterprise: morphological analysis of category, composition and classification]. Ekonomichnyi forum - Economic forum, 3, 136-143. Retrieved from http://lutsk-

4. Chernetska, S. A. (2013). Znachennia analizu aktyviv pidpryiemstva [The role of analysis of enterprise assets]. Retrieved from http://dspace.nbuv.gov.ua/bitstream/handle/123456789/92982/39-Chernetskaya.pdf?sequence=1. [in Ukrainian].

5. Chemchykalenko, R. A., Maiboroda, O. Ye., Liutkina, A. V. (2017). Otsinka efektyvnosti upravlinnia aktyvamy ta pasyvamy pidpryiemstva [Evaluating the effectiveness of asset and liability management enterprises]. Економіка і суспільство - Economy and Society, 11, 485-489. Retrieved from http://www.economyandsociety in. ua/journal/11 ukr/78. pdf. [in Ukrainian].

6. Bazilinska, O. Ya. (2009). Finansovyi analiz: teoriia ta praktyka [Financial analysis: theory and practice]. Kyiv: Tsentr uchbovoi literatury [Educational Literature Center]. [in Ukrainian].

7. Lysevych, S. H., Diachenko, K.O. (2013). Otsinka stanu aktyviv pidpryiemstva ta upravlinnia nymy [Assessment and management of the assets of the enterprise.]. Naukovi pratsi Poltavskoi derzhavnoi ahrarnoi akademii. Seriia: Ekonomichni nauky - Scientific work of Poltava State Agrarian Academy. Economics, 1 (6), 206-210. Retrieved from https://www.pdaa.edu.ua/sites/default/files/nppdaa/6.2/206.pdf. [in Ukrainian].

financial controlling in the field of business]. Finansy Ukrainy - Finance of Ukraine, 11, 66-83. [in Ukrainian].

Реиензент д.е.н., професор Вахович I.М. 